\title{
HORMONAL INTERVENTION IN THE UPTAKE OF AMINO ACIDS BY STAPHYLOCOCCI
}

\author{
T. Fitzgerald AND W. W. Yotis \\ Department of Microbiology, Loyola University (Chicago) \\ Stritch School of Medicine, Maywood, Illinois 60153, USA
}

\begin{abstract}
Previous work (Yotis and Stanke, 1966; Yotis, 1967; Yotis and Fitzgerald, 1968; Yotis and Waner, 1968; Yotis and Baman, 1969) has shown that steroids exert an antimicrobial effect in vitro and in vivo on Staphylococcus aureus, and may play a role in protection against staphylococcal infections. Progesterone and certain important androgens, employed in the pharmacological range of $15-40 \mu \mathrm{g}$ per ml, reduced the growth of Gram-positive organisms in nutrient broth. In addition, staphylococci grew more luxuriantly in serum from control rabbits than in serum from hormone-treated animals. The steroids also effectively retarded the progress of induced furunculosis in rabbits. The present experiments were designed to determine optimum parameters for the hormonal inhibition of the uptake of alanine and glutamic acid by staphylococci, and to correlate this inhibition with the previously observed hormonal intervention in staphylococcal growth.
\end{abstract}

\section{MATERIALS AND METHODS}

Strains. Staph. aureus serotypes IX-XIII (ATCC 12606-12610) were maintained by periodic transfer on nutrient agar slants at $4^{\circ} \mathrm{C}$. The bacteria were tested for glucose and mannitol utilisation under anaerobic conditions according to the method of Hugh and Leifson (1953) and for gelatin liquefaction, pigmentation, haemolysis, and production of both free and bound coagulase by accepted microbiological techniques (Sonnenwirth, 1963). Strains of Shigella flexneri and Salmonella paratyphi were obtained from stock culture collections maintained at the Stritch School of Medicine and were originally from the American Type Culture Collection.

Chemicals. Crystalline progesterone, testosterone, and oestradiol-17 $\beta$ were obtained from Sigma Chemical Company and crystalline diethylstilboestrol from Calbiochem. The purity of the compounds was tested by observation of melting points and maximum absorbancies. A specific amount of hormone was dissolved in 95 per cent. ethanol and diluted to a final concentration of 1 or 2 per cent. ethanol. Control cells were exposed to the 1 or 2 per cent. ethanol. L-Alanine-14C (uniformly labelled, u.1.) and L-glutamic acid-14C (u.1.) were obtained from Amersham/Searle Corporation, Des Plaines, Illinois, with specific activities of 156 and $249 \mathrm{mCi}$ per m.mole respectively.

Amino acid uptake studies. Bacteria were grown to mid-log phase in tryptic soy broth (Difco) on a rotary shaker at $37^{\circ} \mathrm{C}$, harvested by centrifugation, and prepared in smooth suspension as previously described (Yotis and Fitzgerald). All uptake experiments were performed in phosphate buffers (Gomori, 1955) at the indicated $p \mathrm{H}$ values. A measured volume of cells was added to $0.1 \mathrm{mCi}$ of the appropriate amino acid in the presence and absence of the hormone(s). Equal volumes of the suspension were filtered at specified times thereafter through Millipore filters (Millipore Corporation, New Bedford, Mass., $0.45 \mu \mathrm{m}$ 
pore size) pre-saturated with the appropriate unlabelled amino acid at $10^{-3} \mathrm{M}$. The filtermembranes were immediately washed with five volumes of cold buffer, air-dried, and placed in scintillation fluid (Davidson and Feigelson, 1957). The radioactivity of filters was assayed according to the method of Mans and Novelli (1961) in a Packard Tri-carb liquid scintillation spectrometer model 3320.

Statistical analysis. All data were subjected to statistical analysis (Batson, 1956). A " $t$ " test value greater than 2.00 indicates a probability factor of less than 5 per cent. and is statistically significant.

\section{RESULTS}

\section{The effect of bacterial concentration on the hormonal inhibition of amino acid uptake}

The initial experiment was designed to determine the bacterial concentration required for optimal hormonal inhibition of amino acid uptake. To this end,

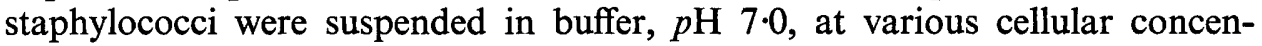

TABLE I

Effect of cell concentration on hormonal inhibition of alanine uptake

\begin{tabular}{|c|c|c|c|c|}
\hline \multirow{2}{*}{$\begin{array}{l}\text { Bacterial concentration } \\
(\mu \mathrm{g} \text { dry wt per } \mathrm{ml})\end{array}$} & \multicolumn{2}{|c|}{$\mu \mathrm{M}{ }^{14} \mathrm{C}$-alanine taken up by } & \multirow{2}{*}{$\begin{array}{l}\text { Difference } \\
\text { (per cent.) }\end{array}$} & \multirow{2}{*}{$\begin{array}{c}\text { " } t \text { "** } \\
\text { for difference }\end{array}$} \\
\hline & control cells & $\begin{array}{l}\text { progesterone- } \\
\text { treated cells }\end{array}$ & & \\
\hline $\begin{array}{r}75 \\
90 \\
125 \\
180 \\
260\end{array}$ & $\begin{array}{l}1 \cdot 20 \\
1 \cdot 80 \\
2 \cdot 25 \\
2.95 \\
4 \cdot 30\end{array}$ & $\begin{array}{l}1.06 \\
1.48 \\
1.95 \\
2.30 \\
3.15\end{array}$ & $\begin{array}{l}11 \cdot 7 \\
17 \cdot 8 \\
13 \cdot 4 \\
22 \cdot 1 \\
26 \cdot 8\end{array}$ & $\begin{array}{l}2.09 \\
2 \cdot 23 \\
2 \cdot 11 \\
2.96 \\
2 \cdot 89\end{array}$ \\
\hline
\end{tabular}

* Values greater than $\mathbf{2 \cdot 0 0}$ are statistically significant.

trations and each suspension was added to a solution of ${ }^{14} \mathrm{C}$-labelled alanine containing progesterone $40 \mu \mathrm{g}$ per $\mathrm{ml}$ in 1 per cent. ethanol. Similar suspensions were added to control tubes that contained ${ }^{14} \mathrm{C}$-alanine in 1 per cent. ethanol without the hormone. Incubation at $24^{\circ} \mathrm{C}$ was terminated by Millipore filtration $8 \mathrm{~min}$. after addition of the label. The data reveal that progesterone significantly reduces the total uptake of the ${ }^{14} \mathrm{C}$-alanine at all bacterial concentrations (table I). Inhibition ranged from 12 to 27 per cent. with maximal effects at the greatest bacterial concentration. All further experiments were performed at a final cellular density equivalent to $260 \mu \mathrm{g}$ dry weight per $\mathrm{ml}$ after addition of the ${ }^{14} \mathrm{C}$-label and the ethanol or ethanol-hormone mixture.

\section{Hormonal effects on various strains of Staph. aureus}

Five strains of staphylococci were suspended in buffer, $p \mathrm{H} 7 \cdot 0$, at $24^{\circ} \mathrm{C}$. The uptake of ${ }^{14} \mathrm{C}$-alanine was examined in the presence and absence of progesterone at a concentration of $40 \mu \mathrm{g}$ per ml. Uptake was terminated $8 \mathrm{~min}$. after addition of the label. Progesterone exerted a significant inhibitory action on all serotypes. A definite variation in the responses of the strains 
to the hormone was observed. Serotype $X$ was the most susceptible whereas serotypes XII and XIII were least susceptible (table II).

TABLE II

Differences in susceptibility to hormonal inhibition of alanine uptake exhibited by various serotypes of Staph. aureus

\begin{tabular}{|c|c|c|c|}
\hline \multirow{2}{*}{ Serotype } & \multicolumn{2}{|c|}{$\mu \mathrm{M}{ }^{14} \mathrm{C}$-alanine taken up by } & \multirow{2}{*}{$\begin{array}{l}\text { Difference } \\
\text { (per cent.) }\end{array}$} \\
\hline & control cells & $\begin{array}{l}\text { progesterone- } \\
\text { treated cells }\end{array}$ & \\
\hline $\begin{array}{r}\underset{X}{\mathbf{I X}} \\
\mathbf{X I} \\
\mathbf{X I I} \\
\mathbf{X I I I}\end{array}$ & $\begin{array}{l}4.99 \\
2 \cdot 73 \\
3.67 \\
4 \cdot 01 \\
4.63\end{array}$ & $\begin{array}{l}4 \cdot 21 \\
2 \cdot 15 \\
3 \cdot 08 \\
3 \cdot 52 \\
4 \cdot 00\end{array}$ & $\begin{array}{l}15.7 \\
21 \cdot 3 \\
16 \cdot 1 \\
12 \cdot 3 \\
13.7\end{array}$ \\
\hline
\end{tabular}

The time-course of the influence of progesterone on the uptake of alanine and glutamic acid

Bacteria were exposed to ${ }^{14} \mathrm{C}$-alanine with and without progesterone at $40 \mu \mathrm{g}$ per ml. Cells were removed from the suspensions at the indicated times and analysed for radioactivity (table III). The uptake of alanine by staphylococci was significantly retarded by the hormone. The inhibition was evident

TABLE III

Time-course study of alanine uptake by staphylococci and its inhibition by progesterone

\begin{tabular}{c|c|c|c}
\hline \multirow{2}{*}{ Time (min.) } & \multicolumn{2}{|c|}{$\mu \mathrm{M}{ }^{14} \mathrm{C}$-alanine taken up by } & \\
\cline { 2 - 3 } & control cells & $\begin{array}{c}\text { progesterone- } \\
\text { treated cells }\end{array}$ & $\begin{array}{c}\text { Difference } \\
\text { (per cent.) }\end{array}$ \\
\hline & & 1.56 & \\
\hline 5 & 1.96 & 2.31 & 18.4 \\
9 & 2.83 & 5.76 & 15.2 \\
45 & 6.79 & 9.57 & 11.2 \\
120 & 10.78 & 11.80 & 13.4 \\
240 & 13.63 & 14.49 & 12.9 \\
\hline
\end{tabular}

during the initial $5 \mathrm{~min}$. and remained relatively constant throughout the incubation period of $240 \mathrm{~min}$. The hormonal inhibition is sustained, even when saturation levels of ${ }^{14} \mathrm{C}$-alanine are approached after $240 \mathrm{~min}$.

Similar results were obtained in a related series of experiments with glutamic acid in the presence of progesterone $40 \mu \mathrm{g}$ per $\mathrm{ml}$. However, the inhibition was observed only during the initial $\frac{1}{2}-7 \mathrm{~min}$. after the addition of the label; thereafter, both control and hormone-treated cells contained equal amounts of ${ }^{14} \mathrm{C}$-activity. 
At this point it was of interest to determine whether the hormonal effects were exerted on the actual transport of the amino acid into the cell, or on the adsorption of the amino acid to the bacterial cell prior to its assimilation. Identical experiments were undertaken with heat-killed organisms $\left(65^{\circ} \mathrm{C}\right.$ for $30 \mathrm{~min}$.) and progesterone at $40 \mu \mathrm{g}$ per $\mathrm{ml}$. The data indicated that the cells adsorbed insignificant amounts of radioactivity, slightly above the background level.

\section{TABLE IV}

Results of comparative studies of the action of progesterone on alanine uptake by bacteria

\begin{tabular}{|c|c|c|c|}
\hline \multirow{2}{*}{$\begin{array}{l}\text { Species tested and details of } \\
\text { observations made }\end{array}$} & \multicolumn{3}{|c|}{$\begin{array}{l}\text { Results obtained at the stated time after } \\
\text { addition of }{ }^{14} \mathrm{C} \text {-alanine }\end{array}$} \\
\hline & $5 \mathrm{~min}$. & $9 \mathrm{~min}$. & $16 \mathrm{~min}$. \\
\hline $\begin{array}{l}\text { Staphylococcus aureus } \\
\text { Index of alanine uptake* by: } \\
\text { control cells } \\
\text { progesterone-treated cells } \\
\text { Difference per cent. } \\
\text { " } t \text { " for difference }\end{array}$ & $\begin{array}{c}32,180 \\
26,060 \\
19 \cdot 1 \\
2 \cdot 15\end{array}$ & $\begin{array}{c}48,260 \\
38,500 \\
20 \cdot 3 \\
2 \cdot 73\end{array}$ & $\begin{array}{c}74,900 \\
55,240 \\
26 \cdot 3 \\
3 \cdot 29\end{array}$ \\
\hline $\begin{array}{l}\text { Shigella flexneri } \\
\text { Index of alanine uptake* by: } \\
\text { control cells } \\
\text { progesterone-treated cells } \\
\text { Difference per cent. } \\
\text { " } t \text { " for difference }\end{array}$ & $\begin{array}{c}13,330 \\
12,960 \\
2 \cdot 8 \\
0.84\end{array}$ & $\begin{array}{c}17,330 \\
17,940 \\
3.5 \\
0.56\end{array}$ & $\begin{array}{c}25,720 \\
25,750 \\
0 \cdot 1 \\
0 \cdot 01\end{array}$ \\
\hline $\begin{array}{l}\text { Salmonella paratyphi } \\
\text { Index of alanine uptake* by: } \\
\text { control cells } \\
\text { progesterone-treated cells } \\
\text { Difference per cent. } \\
\text { " } t \text { " for difference }\end{array}$ & $\begin{array}{c}33,390 \\
34,870 \\
4 \cdot 4 \\
0.01\end{array}$ & $\begin{array}{c}48,830 \\
50,860 \\
4 \cdot 1 \\
1 \cdot 03\end{array}$ & $\begin{array}{c}67,210 \\
69,720 \\
3.7 \\
1.02\end{array}$ \\
\hline
\end{tabular}

* Uptake expressed as counts per minute per $30 \mathrm{ml}$ cells.

\section{Action of progesterone on other micro-organisms}

Previous work (Yotis and Stanke) showed that steroids inhibited the in-vitro growth of Gram-positive micro-organisms such as Staph. aureus and Bacillus subtilis, but did not affect the growth of Gram-negative organisms. Thus, it was important to undertake a related series of experiments with Gramnegative organisms. Shigella flexneri and Salmonella paratyphi were exposed to ${ }^{14} \mathrm{C}$-alanine under identical conditions of $p \mathrm{H}$, temperature, cell concentration, and progesterone at $40 \mu \mathrm{g}$ per $\mathrm{ml}$. The bacteria were removed and assayed for radioactivity at 5,9 and $16 \mathrm{~min}$. after addition of the label. The results given in table IV show that after $5 \mathrm{~min}$. progesterone inhibited staphylococcal alanine uptake 19 per cent.; after 9 min., 20 per cent.; and after $16 \mathrm{~min}$., 
26 per cent. In direct contrast, Sh. flexneri and S. paratyphi, in the presence of hormone, showed no significant variation in the amount of ${ }^{14} \mathrm{C}$-activity taken up compared with that assimilated by corresponding controls.

\section{The effect of hormone concentration}

The extent of the inhibition produced by various progesterone concentrations on alanine uptake is indicated in table V. Cells were exposed to the ${ }^{14} \mathrm{C}$-amino acid in the presence of the hormone at concentrations of 30,20 , 10,1 and $0 \mu \mathrm{g}$ per ml. Bacteria were isolated by membrane filtration $8 \mathrm{~min}$. after addition of the label, and assayed for radioactivity. A progressive increase in inhibition was observed with the increasing concentrations of progesterone.

TABLE V

The degree of inhibition of alanine uptake observed at various progesterone concentrations in tests with Staph. aureus

\begin{tabular}{c|c|c|c}
\hline $\begin{array}{c}\text { Progesterone } \\
\text { concentration } \\
(\mu \mathrm{g} \text { per ml) }\end{array}$ & $\begin{array}{c}\text { Index of } \\
\text { 14C-alanine } \\
\text { uptake* }\end{array}$ & $\begin{array}{c}\text { Difference } \\
\text { (per cent.) }\end{array}$ & $\begin{array}{c}\text { “ } \mathrm{t} \text { " for } \\
\text { difference }\end{array}$ \\
\hline 0 & 43,400 & $\ldots$ & $\ldots$ \\
1 & 40,709 & $6 \cdot 3$ & $1 \cdot 31$ \\
10 & 37,910 & $12 \cdot 7$ & $1 \cdot 87$ \\
30 & 33,250 & $23 \cdot 4$ & $2 \cdot 35$ \\
\hline
\end{tabular}

* Uptake expressed as counts per minute per $30 \mathrm{ml}$ cells.

These results were correlated with those of previous work (Yotis and Stanke; Yotis and Fitzgerald) in which staphylococcal growth was retarded by steroids in the pharmacological range of $15-40 \mu \mathrm{g}$ per ml. It is noteworthy that similar dosages also effectively inhibit the uptake of alanine.

\section{Effect of $p H$}

Because amino acid uptake is mediated by enzyme-like reactions involving permease systems (Cohen and Monod, 1957; Kepes, 1963), it was of interest to observe hormonal effects at various hydrogen ion concentrations. Phosphate buffers were prepared at $p \mathrm{H} 5 \cdot 7,6 \cdot 5,7 \cdot 5$ and 8.0. Cells were exposed to ${ }^{14} \mathrm{C}$-alanine for $8 \mathrm{~min}$. and assayed for radioactivity (table VI). Maximum

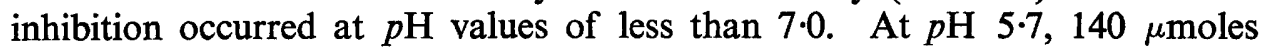
of alanine were taken up by hormonally treated bacteria whereas $275 \mu$ moles

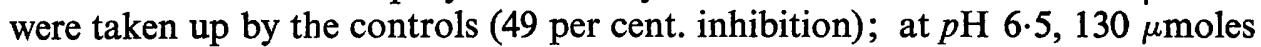
compared with $295 \mu$ moles (56 per cent. inhibition). At $p \mathrm{H}$ values above 6.5 , there was a rapid decline in alanine uptake and correspondingly less marked inhibitory effects.

\section{Effect of other hormones}

The observation that progesterone inhibited the uptake of alanine and glutamic acid prompted a comparative study of the effects of other hormones. 
Bacterial uptake of ${ }^{14} \mathrm{C}$-alanine was observed separately in the presence of progesterone, testosterone and oestradiol- $17 \beta$ at $40 \mu \mathrm{g}$ per ml, and diethylstilboestrol at $20 \mu \mathrm{g}$ per ml. The solubility of the latter compound obliged us

TABLE VI

Hormonal inhibition of alanine uptake by Staph. aureus at various $p H$ values

\begin{tabular}{c|c|c|c|c}
\hline \multirow{2}{*}{$p \mathrm{H}$} & \multicolumn{2}{|c|}{$\mu \mathrm{M}{ }^{14} \mathrm{C}$-alanine taken up by } & $\begin{array}{c}\text { Difference } \\
\text { (per cent.) }\end{array}$ & $\begin{array}{c}\text { “ } \mathrm{t} \text { " for } \\
\text { difference }\end{array}$ \\
\cline { 2 - 3 } & control cells & $\begin{array}{c}\text { progesterone- } \\
\text { treated cells }\end{array}$ & & \\
\hline 5.7 & 2.75 & 1.40 & 49.1 & 4.29 \\
6.5 & 2.95 & 1.30 & 56.0 & 4.43 \\
7.5 & 1.30 & 1.17 & 10.0 & 1.90 \\
8.0 & 0.76 & 0.69 & 9.3 & 1.66 \\
\hline
\end{tabular}

to use 2 per cent. ethanol as the solvent for all four compounds and in the control studies. Cells were removed at 2,5 and $9 \mathrm{~min}$. after addition of the label and assayed for radioactivity. Diethylstilboestrol produced maximum

TABLE VII

Effect of various hormones on the uptake of alanine by Staph. aureus

\begin{tabular}{|c|c|c|c|c|c|c|}
\hline \multirow{3}{*}{$\begin{array}{l}\text { Hormone used } \\
\text { for treatment of } \\
\text { test bacterial } \\
\text { suspension }\end{array}$} & \multicolumn{6}{|c|}{ Test result obtained at the given time after addition of ${ }^{14} \mathrm{C}$-alanine } \\
\hline & \multicolumn{2}{|c|}{$2 \mathrm{~min}}$. & \multicolumn{2}{|c|}{$5 \mathrm{~min}}$. & \multicolumn{2}{|c|}{$9 \mathrm{~min}}$. \\
\hline & $\begin{array}{l}\mu \mathrm{M}{ }^{14} \mathrm{C}- \\
\text { alanine } \\
\text { taken up }\end{array}$ & $\begin{array}{l}\text { " } t \text { " for } \\
\text { difference } \\
\text { from } \\
\text { control }\end{array}$ & $\begin{array}{l}\mu \mathrm{M}{ }^{14} \mathrm{C}- \\
\text { alanine } \\
\text { taken up }\end{array}$ & $\begin{array}{l}\text { " } t \text { " for } \\
\text { difference } \\
\text { from } \\
\text { control }\end{array}$ & $\begin{array}{l}\mu \mathrm{M}{ }^{14} \mathrm{C}- \\
\text { alanine } \\
\text { taken up }\end{array}$ & $\begin{array}{l}\text { " } t \text { " for } \\
\text { difference } \\
\text { from } \\
\text { control }\end{array}$ \\
\hline $\begin{array}{l}\text { Nil (control) } \\
\text { Testosterone, }\end{array}$ & $\begin{array}{l}1 \cdot 74 \\
1 \cdot 56\end{array}$ & $2 \cdot 00$ & $\begin{array}{l}3 \cdot 16 \\
2 \cdot 85\end{array}$ & $1 \dddot{83}$ & $\begin{array}{l}4 \cdot 40 \\
3 \cdot 87\end{array}$ & $2 \cdot 11$ \\
\hline $\begin{array}{l}40 \mu \mathrm{g} \text { per } \mathrm{ml} \\
\text { Progesterone, }\end{array}$ & $1 \cdot 49$ & $2 \cdot 26$ & $2 \cdot 62$ & $2 \cdot 14$ & $3 \cdot 74$ & $2 \cdot 31$ \\
\hline $\begin{array}{l}40 \mu \mathrm{g} \text { per mI } \\
\text { Oestradiol-17 }, \\
40 \mu \mathrm{g} \text { per ml }\end{array}$ & $1 \cdot 52$ & $2 \cdot 14$ & $2 \cdot 67$ & $2 \cdot 22$ & $3 \cdot 78$ & $2 \cdot 09$ \\
\hline $\begin{array}{l}\text { Diethylstilboestrol, } \\
20 \mu \mathrm{g} \text { per ml }\end{array}$ & $0 \cdot 51$ & $4 \cdot 47$ & 0.50 & 3.98 & 0.55 & $4 \cdot 20$ \\
\hline
\end{tabular}

inhibition, retarding uptake by $70-80$ per cent. Testosterone, oestradiol-17 $\beta$ and progesterone exerted relatively less marked inhibitory effects (table VII).

In related experiments, $17 \alpha$-hydroxyprogesterone, which did not retard the growth of Staph. aureus in broth (Yotis and Stanke), produced no inhibitory effects on the uptake of alanine and glutamic acid by staphylococci. 


\section{Discussion}

The data presented indicate that hormones inhibit the uptake of amino acids by Staphylococcus aureus. The following results observed in our present study are correlated with the previously observed retardation of staphylococcal growth in broth (Yotis and Stanke, 1966; Yotis, 1967; Yotis and Fitzgerald, 1968; Yotis and Waner, 1968; Yotis and Baman, 1969): (1) progesterone in amounts exceeding $15 \mu \mathrm{g}$ per $\mathrm{ml}$ inhibited uptake of amino acids; (2) maximum reduction of uptake was obtained with diethylstilboestrol; (3) 17 $\alpha$-hydroxyprogesterone did not significantly alter uptake; and (4) uptake by Gram-negative micro-organisms was not affected by the steroids or by diethylstilboestrol.

The last mentioned observation invites interesting speculation. The steroids retard the growth of staphylococci without penetrating the bacterial cells in significant quantities (Yotis and Fitzgerald), and in some way probably influence extracellular factors in the cell wall or cell membrane. In so doing, direct action may be exerted on specific uptake systems located in the cell membrane, and this in turn retards the growth of the bacteria. A major difference between Gram-negative and Gram-positive organisms is the biochemical structure of the cell wall. A possible explanation of the resistance of Gram-negative organisms to the effect may involve the inability of the organism to bind hormones and thus avoid the postulated subsequent effects on uptake systems.

The $p \mathrm{H}$ dependence of hormonal inhibition may reflect steroidal interaction with the enzyme-like permease systems (Cohen and Monod, 1957; Kepes, $1963)$ for amino acid transport. The data implicate permease systems, in that maximum uptake inhibition (56 per cent.) occurred at that $p \mathrm{H}$ value $(6 \cdot 5)$ associated with maximum uptake of alanine. A further explanation for increase in hormonal inhibition as $p \mathrm{H}$ is lowered is the availability of greater numbers of charged groups in the cell surface, resulting in greater attraction and binding of the hormones. The observation that changes in hormonal inhibition rates correspond to $p \mathrm{H}$ changes of the suspending medium implicate an extracellular mode of action perhaps at the cell wall or cell membrane.

The results of the present work are correlated with those of previous work and indicate parameters that may be of use in elucidating the mechanism of the retardation of the growth of Staph. aureus by these hormones.

\section{SUMMARY}

Hormonal effects on the uptake of amino acids by Staphylococcus aureus have been studied in relation to the reported antibacterial action of the hormones. Progesterone at $40 \mu \mathrm{g}$ per $\mathrm{ml}$ retarded the uptake of ${ }^{14} \mathrm{C}$-alanine and ${ }^{14} \mathrm{C}$ glutamic acid. Diethylstilboestrol, testosterone and oestradiol-17 $\beta$ exerted similar inhibitory effects, whereas $17 \alpha$-hydroxyprogesterone did not. Maximum inhibition of alanine uptake occurred at a cellular density corresponding to $260 \mu \mathrm{g}$ dry weight per $\mathrm{ml}$, at a $p \mathrm{H}$ value between $5 \cdot 7$ and $7 \cdot 0$, and with diethylstilboestrol at a concentration of $20 \mu \mathrm{g}$ per $\mathrm{ml}$. The assimilation of alanine by Shigella flexneri and Salmonella paratyphi was not inhibited by progesterone. The data are correlated with inhibitory phenomena previously observed and 
indicate parameters for further research toward elucidation of the hormonal mechanism of inhibition of Staph. aureus.

This investigation was supported by Public Health Service research grant AI-06618-05 from the National Institute of Allergy and Infectious Diseases.

\section{REFERENCES}

Batson, H. C. 1956. An introduction to statistics in the medical sciences, Minneapolis, p. 16.

Cohen, G. N., ANd Monod, J. 1957. Bacterial permeases. Bact. Rev., 21, 169.

Davidson, J. D., AND Feigelson, P. 1957. Practical aspects of internal-sample liquidscintillation counting. Int. J. Appl. Radiat. Isotopes, $2,1$.

GOMORI, G. 1955. Preparation of buffers for use in enzyme studies. In Methods in enzymology, edited by S. P. Colowick and N. O. Kaplan, New York, vol. 1, p. 143.

HUGH, R., AND LeIrSON, E. 1953. The taxonomic significance of fermentative versus oxidative metabolism of carbohydrates by various gram negative bacteria. J. Bact., 66, 24 .

KePes, A. 1963. Permeases: identification and mechanism. Recent Prog. Microbiol., 8, 38.

MaNs, R. J., AND Novelli, G. 1961. Measurement of the incorporation of radioactive amino acids into protein by a filter-paper disk method. Archs Biochem. Biophys., 94, 48.

SONNENWIRTH, A. 1963. Gram positive and gram negative cocci. In Gradwohl's Clinical laboratory methods and diagnosis, 6th ed., edited by S. Frankel and S. Reitman, $S t$ Louis, p. 537.

YoтIs, W. W. 1967. In vivo and in vitro action of norethindrone on staphylococci. J. Bact., 94, 1353.

YotIs, W. W., AND BAMAN, S. 1969. An evaluation of diethylstilbestrol as an inhibitor of the growth of staphylococci. Yale J. Biol. Med., 41, 311.

Yotis, W. W., AND FITZGERALD, T. 1968. Responses of staphylococci to androgens. Appl. Microbiol., 16, 1512.

Yotis, W. W., AND Stanke, R. 1966. Bacteriostatic action of progesterone on staphylococci and other microorganisms. J. Bact., 92, 1285.

YoTIS, W. W., AND WANER, J. 1968. Antimicrobial properties of testosterone and its intermediates. Antonie van Leeuwenhoek, 34, 275. 